\title{
Article \\ Olfactory Response of Mahanarva spectabilis (Distant, 1909) (Hemiptera: Cercopidae) to Volatile Aqueous Extracts of Plant Origin Applied to Elephant Grass Plants (Pennisetum purpureum Schum)
}

\author{
Vinícius Ferraz Nascimento ${ }^{1}$, Alexander Machado Auad ${ }^{2, *(\mathbb{D})}$ and Tiago Teixeira de Resende ${ }^{2}$ \\ 1 Department of Biodiversity and Nature Conservation, Federal University of Juiz de Fora, \\ Juiz de Fora 36036900, Minas Gerais, Brazil; vinicius.nascimento@icb.ufjf.br \\ 2 Laboratory of Entomology, Embrapa Dairy Cattle, Juiz de Fora 36038330, Minas Gerais, Brazil; \\ tiago.resende@embrapa.br \\ * Correspondence: alexander.auad@embrapa.br
}

Citation: Nascimento, V.F.; Auad, A.M.; de Resende, T.T. Olfactory Response of Mahanarva spectabilis (Distant, 1909) (Hemiptera: Cercopidae) to Volatile Aqueous Extracts of Plant Origin Applied to Elephant Grass Plants (Pennisetum purpureum Schum). Agronomy 2021, 11, 856. https://doi.org/10.3390/ agronomy 11050856

Academic Editors: Patrick Pageat and Andrea Liliana Clavijo McCormick

Received: 12 March 2021

Accepted: 18 April 2021

Published: 28 April 2021

Publisher's Note: MDPI stays neutral with regard to jurisdictional claims in published maps and institutional affiliations.

Copyright: (c) 2021 by the authors. Licensee MDPI, Basel, Switzerland. This article is an open access article distributed under the terms and conditions of the Creative Commons Attribution (CC BY) license (https:/ / creativecommons.org/licenses/by/ $4.0 /)$.

\begin{abstract}
In this study, we evaluate the olfactory responses of Mahanarva spectabilis adults to aqueous extracts from the following non-host plants for the pest insect: garlic (Allium sativum L.), rue (Ruta graveolens L.), cinnamon (Cinnamomum verum J. Presl), lemongrass (Cymbopogon citratus Stapf.), clove (Syzygium aromaticum L.), star anise (Illicium verum Hook.f), eucalyptus (Eucalyptus globulus Labill.), tobacco (Nicotiana tabacum L.), and thyme (Thymus vulgaris L.) applied to the host plant, elephant grass (Pennisetum purpureum Schum.). The bioassays were performed using a Y olfactometer, and the combinations of the plant extracts applied to the host plant were tested against fresh air and against the host plant without the extract. The results show that the extracts of tobacco and star anise were non-attractive to $M$. spectabilis adults. The extracts from the remaining plants did not alter the response of $M$. spectabilis to the host plant.
\end{abstract}

Keywords: agroecology; repellency; spittlebugs; volatile organic compounds

\section{Introduction}

In Latin America, most animal production is based on grazing, which is often planned in those areas where the soil is unsuitable for other agricultural activities. Consequently, serious levels of degradation occur in considerable parts of the grazing areas, which proves to be a limiting factor in the production of meat and milk [1]. Additionally, besides the complex agroecological process, biotic factors such as insect pests contribute substantially to the degradation of the pastures [2].

Among the most important insect pests associated with the pastures are spittlebugs. The attack of these insects occurs mainly in the rainy season of the year, which causes a fall in the production of forage, precisely in the period of high demand by cattle; thus, it thoroughly damages the chains of beef and milk production [3,4]. According to Thompson [5], damage by spittlebugs on pastures generates losses of up to the USD 2.1 billion per year worldwide. In Brazil, the spittlebug Mahanarva spectabilis (Distant, 1909) (Hemiptera: Cercopidae) is considered an obstacle to forage production and is the main and most limiting pest associated with the production of elephant grass (Pennisetum purpureum Schum. (Poales: Poaceae)) [6].

Female spittlebugs $M$. spectabilis lay eggs close to the forage base, and the eggs are elongated and resemble the shape of a yellow-colored rice grain [7,8]. After hatching, the nymphs immediately fix themselves on the roots and synthesize a foam, in which they are immersed for five instars until they reach adulthood. The foam protects them against natural enemies and provides a microclimate that is favorable for their development $[8,9]$. Adults, unlike nymphs, have wings and reproductive organs and move around in low 
jumps and short flights $[8,10]$. They have an average longevity rate of 9 days $( \pm 3)$ in females and 10 days $( \pm 4)$ in males [11]. They prefer to stay fixed in the sheaths of forage leaves, sucking the sap and injecting toxins that cause yellowing and death of the plant tissues [12]. Hence, it is important to have necessary strategies for the control of such pests.

Spittlebug management strategies must be used together so that the control of this pest is sustainable and efficient. Among the management strategies used in Brazil, we highlight the diversification of pastures [13], chemical control [14], biological control [15,16], and the use of resistant plants [17]. The use of insecticides and botanical repellents is a widespread strategy, and studies of this nature are necessary for the management of forage pests.

Dias et al. [18] demonstrated that compounds of plant origin are effective against the spittlebug $M$. spectabilis. It must be considered that plants present phytochemicals in their constitution with unique biological characteristics that play different structural roles and act as larvicides [19], insecticides [18], repellents [20], ovipositional regulators [21], and growth regulators [22], which partially help them avoid the attacks of the phytophagous insects. The unattractive or attractive action of the plants is closely related to the volatile organic compounds (VOCs) released by the plants. VOCs act to defend the plant by promoting protection against abiotic and biotic stresses. Moreover, they also play crucial roles in the ecological interactions of the plants with the other organisms [23,24]. These compounds have great potential for their use in integrated pest management once they are obtained through the manufacturing of plant extracts.

The push-pull technique uses the principles of attraction and non-attractiveness to manipulate the behavior of the insect pests through the integration of the stimuli that act to repel or drive the pests away from the main crop (push) while attracting them towards a source crop (pull) by using highly apparent and attractive stimuli. Hence, the pests are subsequently removed away from the desired crop. The attractive or unattractive action of a plant can be natural when generated by the aromatic compounds present in the host plant; however, if this is not the case, it can also be induced externally by the application of stimuli that can mask the host appearance in terms of repellency, deterrence, and attraction [25]. As an example, researchers demonstrated that the choice of a host plant by M. spectabilis can be attributed to the specific odors released by forage, such as Pennisetum purpureum $\mathrm{cv}$. Pioneiro and Brachiaria decumbens cv. Basilisk [26]. They also demonstrated that damaged plants of Brachiaria brizantha cv. Marandú unattracted the adults of $M$. spectabilis.

The aforementioned research results served to hypothesize that the aqueous extracts of certain aromatic non-host plants after their application to elephant grass may alter the attractive response of elephant grass to $M$. spectabilis. The present research is an effort to arrive and identify those suitable non-host plant extracts. Therefore, the objective of this research is to evaluate the olfactory response of the adults of the spittlebug $M$. spectabilis towards the aqueous extracts of the aromatic plants (non-hosts to these insects), such as Allium sativum L. (Amaryllidaceae), Ruta graveolens L. (Rutaceae), Cinnamomum verum J. Presl. (Lauraceae), Cymbopogon citratus Stapf. (Poaceae), Syzygium aromaticum L. and Eucalyptus globulus Labill. (Myrtaceae), Illicium verum Hook.f (Schisandraceae), Nicotiana tabacum L. (Solanaceae), and Thymus vulgaris L. (Lamiaceae), when they are applied to the host plant, the elephant grass (Pennisetum purpureum Schum. (Poaceae)).

\section{Materials and Methods}

\subsection{Botanical Material and Plant Extracts}

For the olfactometry tests, elephant grass (Pennisetum purpureum Schum) was used. It was obtained by using cuttings (10 $\mathrm{cm}$, single knot), from the Experimental Field of Embrapa Dairy Cattle, Coronel Pacheco, Brazil. The cuttings were propagated in plastic pots $(500 \mathrm{~mL})$ that contained the substrate (soil/manure in a 1:1 ratio) to form the seedlings. The seedlings were kept in a greenhouse at Embrapa Dairy Cattle in Juiz de Fora, MG, Brazil, until they reached an approximate height of $30 \mathrm{~cm}$ and were used in the experiments.

The botanical materials for making the plant extracts were obtained from different sources (Table 1). With the exception of eucalyptus leaves, the other materials were 
purchased from the commercial establishments described in Table 1. For lemon grass, rue, and thyme, seedlings were purchased, and they were planted in $1 \mathrm{~L}$ plastic pots and stored in an Embrapa Dairy Cattle greenhouse for 3 months, with daily irrigation, before use. Garlic, cinnamon, cloves, tobacco, and anise star were purchased in their whole form, ready for use. Eucalyptus leaves were collected from trees at the Experimental Field of Embrapa Dairy Cattle.

Table 1. List of plant species, their sources, forms of acquisition, and parts used to make the aqueous plant extracts.

\begin{tabular}{|c|c|c|c|c|}
\hline Extract & Plant Species & Sources & Forms of Acquisition & Parts Used \\
\hline Garlic & Allium sativum L. & Street Fair, Juiz de Fora, MG, Brazil & Whole product & Bulbs \\
\hline Star anise & Illicium verum Hook.f & $\begin{array}{l}\text { Municipal Market of Juiz de Fora, } \\
\text { MG, Brazil }\end{array}$ & Dry parts & Fruits \\
\hline Rue & Ruta graveolens L. & $\begin{array}{c}\text { Municipal Market of Juiz de Fora, } \\
\text { MG, Brazil }\end{array}$ & Seedlings & Leaves \\
\hline Cinnamon & Cinnamomum verum J. Presl & $\begin{array}{l}\text { Municipal Market of Juiz de Fora, } \\
\text { MG, Brazil }\end{array}$ & Dry parts & Bark \\
\hline Lemongrass & Cymbopogon citratus Stapf. & $\begin{array}{l}\text { Municipal Market of Juiz de Fora, } \\
\text { MG, Brazil }\end{array}$ & Seedlings & Leaves \\
\hline Clove & Syzygium aromaticum L. & $\begin{array}{l}\text { Municipal Market of Juiz de Fora, } \\
\text { MG, Brazil }\end{array}$ & Dry parts & Flower bud \\
\hline Eucalyptus & Eucalyptus globulus Labill. & $\begin{array}{c}\text { Embrapa Dairy Cattle, Coronel } \\
\text { Pacheco, MG, Brazil }\end{array}$ & Collected leaves & Leaves \\
\hline Tobacco & Nicotiana tabacum L. & $\begin{array}{l}\text { Municipal Market of Juiz de Fora, } \\
\text { MG, Brazil }\end{array}$ & Dry parts & Leaves \\
\hline Thyme & Thymus vulgaris L. & $\begin{array}{l}\text { Municipal Market of Juiz de Fora, } \\
\text { MG, Brazil }\end{array}$ & Seedlings & Leaves \\
\hline
\end{tabular}

Nine plant extracts (Table 1) were prepared at the Entomology Laboratory of Embrapa Dairy Cattle, Juiz de Fora, Brazil. Each plant extract was made separately on the day before the olfactometry tests were performed. For the preparation of the extracts, parts from the selected plants (Table 1) were washed with distilled water and then placed in a forced ventilation oven (Binder FD115) for drying at an average temperature of $40^{\circ} \mathrm{C}$ for $72 \mathrm{~h}$.

After drying, the materials were ground in a basic analytical mill IKA ${ }^{\circledR}$ model A11 and placed in the beakers, which were filled with distilled water at a concentration of $20 \%$ and taken to an ultrasound shaker (ELMA E60H) to extract the compounds. The resulting solutions were filtered through a voile fabric, which gave rise to the aqueous plant extracts. The plant extracts were stored in amber glass bottles and protected from the light until the olfactometry tests.

\subsection{Insects}

For the performance of the olfactometry tests, adult $M$. spectabilis specimens were collected from the elephant grass plants in the Experimental Field and greenhouses of Embrapa Dairy Cattle. Later, they were taken to the entomology laboratory, where they were kept in acrylic cages $\left(30 \times 30 \times 60 \mathrm{~cm}^{3}\right)$ at room temperature $\left(25 \pm 2{ }^{\circ} \mathrm{C}\right)$. Females and males of this insect were used in undefined proportions. Adult collections were performed on different dates in the morning before each trial.

\subsection{Bioassays of Olfactometry}

The olfactometry bioassays were carried out at the Embrapa Dairy Cattle Entomology Laboratory. The experimental procedure by Silva et al. [26] was used with adaptations. A Y-type glass olfactometer was used, with the following dimensions: the main arm, $30 \mathrm{~cm}$; the side arms, $23 \mathrm{~cm}$; diameter, $3.5 \mathrm{~cm}$; with an angle of $120^{\circ}$ between the arms. The airflow was continuous at $1.0 \mathrm{~L} / \mathrm{min}$, and the air was humidified with distilled water, filtered with activated carbon, and calibrated with the help of a flow meter. For the insertion of the plants, a glass dome with $42 \mathrm{~cm}$ height and with a diameter of $16 \mathrm{~cm}$ was attached to each 
arm of the olfactometer with the help of silicone tubes. The plastic cups that contained the elephant grass plants were wrapped in the aluminum foils to reduce the volatile effects of the substrate.

The tests were carried out between 9 a.m. and 4 p.m. from December 2019 to March 2020. The average temperature during the test period was $27 \pm 2{ }^{\circ} \mathrm{C}$, the relative humidity was $60 \pm 10 \%$, and the photophase was 12:12 $\mathrm{h}$. Before performing the bioassays, the olfactometer was calibrated, noting the $M$. spectabilis responses to the combination clean air vs. clean air. In the tests, the extracts of the non-host plants were applied directly to the leaves of the host plants (elephant grass) through a plastic sprayer of $500 \mathrm{~mL}, 10$ sprays for each plant extract $(\cong 8 \mathrm{~mL})$, forming a combination of the aqueous plant extract + elephant grass. All aqueous plant extracts were tested against fresh air and host plants (without extract). The tests proceeded with the following combinations: (1) garlic extract + elephant grass vs. clean air; (2) garlic extract + elephant grass vs. elephant grass; (3) star anise extract + elephant grass vs. clean air; (4) star anise extract + elephant grass vs. elephant grass; (5) rue extract + elephant grass vs. clean air; (6) rue extract + elephant grass vs. elephant grass; (7) cinnamon extract + elephant grass vs. clean air; (8) cinnamon extract + elephant grass vs. elephant grass; (9) lemongrass extract + elephant grass vs. clean air; (10) lemongrass extract + elephant grass vs. elephant grass; (11) clove extract + elephant grass vs. clean air; (12) clove extract + elephant grass vs. elephant grass; (13) eucalyptus extract + elephant grass vs. clean air; (14) eucalyptus extract + elephant grass vs. elephant grass; (15) thyme extract + elephant grass vs. clean air; (16) thyme extract + elephant grass vs. elephant grass; (17) tobacco extract + elephant grass vs. clean air; (18) tobacco extract + elephant grass vs. elephant grass.

M. spectabillis adults were removed from the acrylic cages and placed in the voile fabric cages before each bioassay. The tests with the insects were carried out individually, where each adult was placed on the base of the olfactometer. The responses were counted and considered positive only for the insects that reached the end of one of the lateral arms of the $\mathrm{Y}$ within $10 \mathrm{~min}$. The insects that did not reach the lateral arms in this period were quantified, but they were not included in the analysis. For each bioassay, 40 positive responses were evaluated.

To maintain the equipment and to avoid any external interference in the responses of the insects, the following operations were performed: After 5 insects were tested, the olfactometer was washed with $96^{\circ}$ ethyl alcohol and dried in an oven at $100{ }^{\circ} \mathrm{C}$. The olfactometer was also rotated $180^{\circ}$ to avoid any positional bias. After 10 tests, the olfactometer and the domes were washed in distilled water with neutral detergent and alcohol and dried in an oven at $100^{\circ}$. Additionally, after every 10 tests, the plants from the dome were changed, and aqueous plant extracts were reapplied. At each odor source change, that is, after 40 positive responses, the silicone hoses were replaced and all the equipment and the olfactometer and its parts were washed in distilled water with neutral detergent and alcohol and dried in an oven at $100^{\circ} \mathrm{C}$.

\subsection{Statistical Analysis}

The results were analyzed using the Chi-square test $\left(\chi^{2}\right)$ in the BioEstat 5.4 software [27]. Insects that chose neither arm were excluded from the statistical analysis.

\section{Results}

M. spectabilis had no significant difference $\left(\chi^{2}=0 ; \mathrm{DF}=1 ; p=0.9999\right)$ when clean air was tested in both arms, which indicated that there was no positional bias in the olfactometer.

The combination of the host plant with the tobacco extract resulted in non-attractiveness. In this adjustment, $70 \%$ of the $M$. spectabilis went to fresh air $\left(\chi^{2}=6.4 ; \mathrm{DF}=1 ; p=0.0114\right)$ and $77.5 \%$ to the elephant grass without the extract $\left(\chi^{2}=12.1 ; \mathrm{DF}=1 ; p=0.0005\right)$ (Figure $\left.1 \mathrm{~A}, \mathrm{~B}\right)$. 

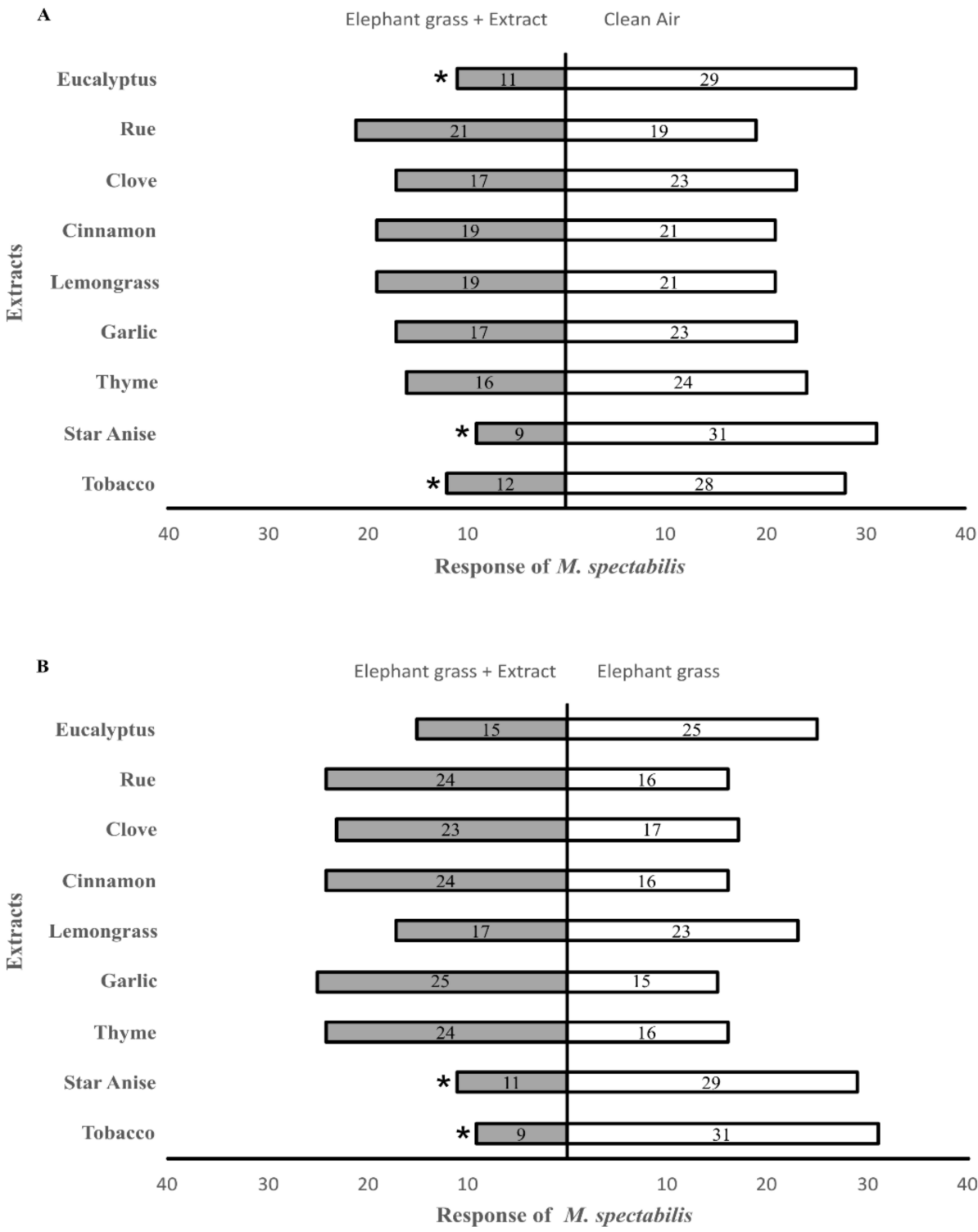

Figure 1. Behavioral response of $M$. spectabilis adults to the volatiles emitted by the combinations of the extracts with the elephant grass, against clean air (A) and host plant (elephant grass) (B) and olfactometry bioassays. The numbers inside the bars are the total number of spittlebugs that responded to each treatment. ${ }^{*}$ ) There was a significant difference in this treatment.

The star anise extract combination was also deprecated in relation to the clean air $\left(\chi^{2}=12.1 ; \mathrm{DF}=1 ; p=0.0005\right)$ and elephant grass $\left(\chi^{2}=8.1 ; \mathrm{DF}=1 ; p=0.0044\right)$, presenting non-attractiveness to the adults of $M$. spectabillis respectively, with indexes of $77.5 \%$ and $72.5 \%$ (Figure $1 \mathrm{~A}, \mathrm{~B}$ ).

The combination with the aqueous eucalyptus extract was non-attractive in relation to the fresh air $\left(\chi^{2}=8.1 ; \mathrm{DF}=1 ; p=0.0044\right)$, indicating a non-attractive response of $72.5 \%$; however, it was not significantly attractive or unattractive to the adults of $M$. spectabillis, when tested against the elephant grass plants $\left(\chi^{2}=2.5 ; \mathrm{DF}=1 ; p=0.1138\right.$ ) (Figure $\left.1 \mathrm{~A}, \mathrm{~B}\right)$.

Trials using thyme, garlic, cinnamon, lemongrass, rue, and clove extracts, in combination with the elephant grass, were not significantly attractive or unattractive to the $M$. spectabilis when they were tested against the clean air or the elephant grass plants (Figure 1A,B). 


\section{Discussion}

As plants are confronted daily with herbivores, throughout history, they have developed several mechanisms that act in resistance to these herbivores, such as the ability to recognize attacks and reconfigure their responses to produce, among other compounds, volatile organics (VOCs) [24,28]. In this study, we investigated whether the volatile compounds present in the aqueous extracts of the nine species of plants with insecticidal potential, applied on the forage host, would be able to alter the adult spittlebugs' (M. spectabilis) choice of pastures, influencing their behavior of attraction or non-attraction. Elephant grass was chosen since it can release some specific odors that have the potential to attract M. spectabilis [26].

The M. spectabilis responded significantly to the olfactory cues released by the combinations of the host plant with the extracts of the star anise, tobacco, and eucalyptus in the bioassays against the clean air (bioassay A) and the combinations of the host plant with the star anise and tobacco extracts in relation to the host plant without plant extract (bioassay B). The observed non-attraction of $M$. spectabilis to the volatile compounds of the star anise, tobacco, and eucalyptus extracts is added to the observations of Silva et al. [26] on the attraction of adult $M$. spectabilis elephant grass and reveals a change in the behavior of M. spectabilis by the application of the plant extracts. Similarly, Cook et al. [25] mention that the behavior of non-attractiveness can occur if the odor reveals a low-quality host, and non-attraction can occur after the application of non-host plant odors.

Some authors have observed that the extracts and oils made from star anise have non-attractive effects on the insects. Singh and Singh [29] obtained 100\% non-attractiveness from Musca domestica L. (Diptera: Muscidae) by using the essential oil of star anise. The researchers Wei et al. [30] noted that the non-attractiveness of the star anise extracts increased as the doses increased. The highest percentage of non-attractiveness observed by the authors on the adults of Sitophilus zeamais Motschulsky (Coleoptera, Curculionidae) was $76.9 \%$. In the research by Matos et al. [31], with a concentration of $32.78 \mu \mathrm{L} / 20 \mathrm{~g}$, the star anise essential oil repelled the adults of Callosobruchus maculatus (Fabr.) (Coleoptera: Bruchidae). The main bioactive compound present in star anise is trans-anethole, which is an aromatic compound responsible for the aroma and flavor of anise [30,32]. This substance is not attractive for different species of pests, as also noted for M. spectabilis in the present research.

Tobacco has been used by humans to control insect pests since the 17th century, mainly due to its high efficiency, low phytotoxicity, and low cost [33-35]. Given its properties, tobacco extract is also attributed with being non-attractive to pests. The main bioactive compound present in the tobacco extract is nicotine, which in its volatile form is possibly responsible for the non-attractive action against $M$. spectabilis as observed by Sagheer et al. [36]. The acetonic tobacco extract obtained the highest non-attractiveness index (93.33\%) among the four extracts tested against Tribolium castaneum (Herbst) [37,38].

The volatile compounds present in the species of the Eucalyptus genus have shown promising results in the control of several insects. González-Guiñez et al. [39] proved that the essential oil of E. globulus is non-attractive for S. zeamais adults. Descamps et al. [40] found that the essential oil of E. globulus, at a concentration of $7 \% w / v$, was non-attractive for Acyrthosiphon pisum Harris (Hemiptera: Aphididae) adults. The main bioactive compounds present in E. globulus are $\rho$-cymene, $\gamma$-terpinene, and 1.8 cineol (eucalyptol), and the synergistic activity of these and other compounds are responsible for the elaborated action of the E. globulus plants on different species of the insects [41]. In the present work, the aqueous extract of the E. globulus was not attractive to M. spectabilis as compared to clean air; however, when compared to the host plant combination, there was no change.

In the olfactometer tests, the combinations of the host plant with the aqueous extracts of garlic, rue, cinnamon, lemongrass, cloves, and thyme did not alter the behavior of the M. spectabilis adults significantly. A similar situation was reported by Silva et al. [26], who observed that VOCs from P. purpureum cv. Roxo Botucatu, Panicum maximum cvs. Makueni and Tanzania, Hyparrhenia rufa cv. Jaraguá, Melinis minutiflora, Cynodon dactylon 
cv. Tifton, and Brachiaria brizantha cv. Marandú were not significantly attractive or repellent for M. spectabilis. Nonetheless, previous research shows that the application of the extracts prepared from garlic, rue, cinnamon, lemongrass, cloves, and thyme revealed behavioral changes of other insect species. Mobki et al. [42] reported that the garlic extract had a strong non-attractive activity for T. castaneum. Perera and Karunaratne [43] identified strong non-attractiveness (91\%) of the aqueous extract of rue against Sitophilus oryzae L. adults (Coleoptera: Curculionidae). Prajapati et al. [44] demonstrated that the cinnamon essential oil has a high degree of repellency on Anopheles stephensi Liston, Aedes aegypti (L.), and Culex quinquefasciatus (Say) (Diptera: Culicidae). Kimutai et al. [45] reported in their research that lemongrass essential oil showed high non-attractiveness for Phlebotomus duboscqi Neveu-Lemaire (Diptera: Psychodidae), which is one of the main vectors of zoonotic cutaneous leishmaniasis in East Africa. Abo-El-Saad et al. [33] used the essential oil of clove for Tribolium castaneum (Herbest) (Coleoptera: Tenebrionidae) adults and obtained $100 \%$ repellency at concentrations of $1.0 \%, 0.8 \%$, and $0.2 \%$. Picard et al. [46] observed that the essential oil of thyme, in a concentration of $0.5 \%$, was highly non-attractive for the females of Frankliniella occidentalis (Pergande) (Thysanoptera: Thripidae). Despite these compounds inducing a clear behavioral change in some other pest species, as mentioned above, the results obtained in the present study showed that $M$. spectabilis remained unchanged in its comportment in terms of attraction or non-attraction to the host plant upon exposure to the extracts of these plants.

The current analysis is the first to show that plant extracts can alter the behavior of M. spectabilis in relation to their host plant. It has been shown that the application of aqueous extracts of tobacco and star anise can mask specific odors of elephant grass. The nonattractive action of eucalyptus in one of the bioassays is a topic for further research.

The results are encouraging against farmers' growing demand for environmentally safe and non-toxic products [47]. The extracts of tobacco and star anise can complement the techniques of handling M. spectabilis in small properties, such as by the push-pull pest management technique [25].

\section{Conclusions}

Aqueous extracts of tobacco, star anise, and eucalyptus were not attractive for $M$. spectabilis, and therefore can be used as a management tactic for $M$. spectabilis adults in elephant grass. The extracts of thyme, garlic, clove, rue, cinnamon, and lemongrass were not significantly attractive to $M$. spectabilis in the pastures.

Author Contributions: V.F.N. and A.M.A., methodology; V.F.N. and A.M.A., investigation; all authors, resources; A.M.A., data curation; V.F.N. and A.M.A., writing-original draft preparation; V.F.N. and A.M.A., writing — review and editing; all authors, visualization; all authors, supervision. All authors have read and agreed to the published version of the manuscript.

Funding: This work was supported by the Coordination for the Improvement of Higher Education Personnel (Coordenação de Aperfeiçoamento de Pessoal de Nível Superior-CAPES), Brazil (Finance Code 001); Conselho Nacional de Desenvolvimento Científico e Tecnológico (CNPq), Brazil (Finance Code 304281/2019-0); Fundação de Amparo à Pesquisa do Estado de Minas Gerais (FAPEMIG, Brazil (Finance Code CAG APQ-00732-18); and the Embrapa Dairy Cattle (Embrapa Gado de Leite), Brazil.

Institutional Review Board Statement: Not applicable.

Acknowledgments: The authors express their gratitude to the Entomology Laboratory team in the Embrapa Dairy Cattle, the CAPES, the CNPq, and the FAPEMIG for supporting this research. We also thank the Graduate Program in Biodiversity and Nature Conservation at the Federal University of Juiz de Fora (Universidade Federal de Juiz de For a-UFJF), Brazil.

Conflicts of Interest: The authors declare no conflict of interest. 


\section{References}

1. De Andrade Lira, M.; De Mello, A.C.L.; Da Cunha, M.V.; Mércia, V.; Dos Santos, M.V.F.; Duneaux, J.C.B., Jr.; de Andrade Lira, M., Jr.; de Oliveira Apolinário, V.X. Animal production in tropical pastures of Latin America. Arch. Latinoam. Prod. Anim. 2017, 25, $1-2$.

2. Hohnwald, S.; Kato, O.; Walentowski, H. Accelerating capoeira regeneration on degraded pastures in the northeastern amazon by the use of pigs or cattle. Sustainability 2019, 11, 1729. [CrossRef]

3. Congio, G.F.D.S. Caracterização e Quantificação dos Danos Causados por Cigarrinhas Adultas do Gênero Mahanarva sp. (Hemiptera: Cercopidae) em Brachiaria brizantha cv. Marandu. Master's Dissertation, ESALQ-University of Sao Paulo, Piracicaba, Brazil, 2010.

4. Ribeiro, L.P.; Cazarotto, A.R. Cigarrinhas-das-pastagens em Santa Catarina: Avaliação do complexo de espécies e da incidência natural de fungos entomopatogênicos. Agropecuária Catarinense 2019, 32, 73-79. [CrossRef]

5. Thompson, V. Associative nitrogen fixation, C 4 photosynthesis, and the evolution of spittlebugs (Hemiptera: Cercopidae) as major pests of neotropical sugarcane and forage grasses. Bull. Entomol. Res. 2004, 94, 189-200. [CrossRef]

6. Auad, A.M.; Simões, A.D.; Pereira, A.V.; Braga, A.L.F.; Sobrinho, F.S.; Lédo, F.J.D.S.; Paula-Moraes, S.V.; Oliveira, S.A.; Ferreira, R.B. Seleção de genótipos de capim-elefante quanto à resistência à cigarrinha-das-pastagens. Pesq. Agropec. Bras. 2007, 42, 1077-1081. [CrossRef]

7. Valério, J.R. Cigarrinhas-Das-Pastagens; Embrapa Gado de Corte: Campo Grande, Brazil, 2009; 51p.

8. Batista, E.; Auad, A.M.; Braga, A.L.F.; Ferreira, R.B.; Hallack, N.M.d.R. Aspectos do comportamento da cigarrinha-das-pastagens Mahanarva spectabilis (Distant) (Hemiptera: Cercopidae) na produção de espuma. EntomoBrasilis 2010, 3, 25-28. [CrossRef]

9. Souza, J.C.; Silva, R.A.; Reis, P.R.; Queiroz, D.S.; Silva, D.B. Cigarrinhas-Das-Pastagens: Histórico, Bioecologia, Prejuízos, MonitorAmento e Medidas de Controle; EPAMIG: Belo Horizonte, Brazil, 2008; 8p.

10. Menezes, M.; El-Kadi, M.K.; Pereira, J.M.; Ruiz, M.A.M. Bases para o Controle Integrado Das Cigarrinhas Das Pastagens na Região Sudeste da Bahia; CEPLAC-CEPEC: Ilhéus, Brazil, 1983; 33p.

11. Guimarães, F.C.; Paula-Moraes, S.V.; Nunes, R.V.; Pontes, R.A.; Auad, A.M.; Takada, S.C.S. Biologia de ovos e adultos de Mahanarva spectabilis (Distant, 1909) (Hemiptera: Cercopidae). In III Encontro de Jovens Talentos da Embrapa Cerrados, 1st ed.; Faleiro, F.G., de Andrade, S.R.M., Eds.; Embrapa Cerrados: Planaltina, Brazil, 2007; p. 21.

12. Byers, R.; Wells, H.D. Phytotoxemia of Coastal bermudagrass caused by the two-lined spittlebug, Prosapia bicincta (Homoptera: Cercopidae). Ann. Entomol. Soc. Am. 1966, 59, 1067-1071. [CrossRef]

13. Alvarenga, R.; Auad, A.M.; Moraes, J.C.; Da Silva, S.E.B.; Rodrigues, B.S. Tolerance to nymphs and adults of Mahanarva spectabilis (Hemiptera: Cercopidae) by forage plants in fertilized soils. Pest. Manag. Sci. 2019, 75, 2242-2250. [CrossRef]

14. Sutil, W.P.; Santos, R.S.; De Oliveira, L.C. Controle químico de cigarrinhas-das-pastagens no estado do Acre. In A Contribuição da Ciência para a Agropecuária no Acre: Anais, Proceedings of the Seminário da Embrapa Acre de Iniciação Científica e Pós-Graduação, Rio Branco, Brazil, 10-11 September 2019; Álvares, V.d.F., Estanislau, F.M., Eds.; Embrapa Acre: Rio Branco, Brazil, 2020.

15. Campagnani, M.O.; Campos, W.G.; Amorim, S.S.; Rosa, L.H.; Auad, A.M.; Cangussú, M.A.; Maurício, R.M. Prospection and fungal virulence associated with Mahanarva spectabilis (Hemiptera: Cercopidae) in an Amazon silvopastoral system. Florida Entomol. 2017, 100, 426-432. [CrossRef]

16. Veríssimo, B.A.; Auad, A.M.; Oliveira, C.M.; Paiva, I.G. Seasonality of predatory insects (Diptera: Syrphidae and Asilidae) in pasture monoculture and silvopastoral systems from Southeast Brazil. Int. J. Trop. Insect Sci. 2020, 40, 1-12. [CrossRef]

17. Sobrinho, F.S.; Auad, A.M.; da Silva Lédo, F.J. Genetic variability in Brachiaria ruziziensis for resistance to spittlebugs. Crop Breed. Appl. Biotechnol. 2010, 10, 89-94. [CrossRef]

18. Dias, M.L.; Auad, A.M.; Magno, M.C.; Resende, T.T.; Fonseca, M.G.; Silva, S.E. Insecticidal activity of compounds of plant origin on Mahanarva spectabilis (Hemiptera: Cercopidae). Insects 2019, 10, 360. [CrossRef]

19. Otabor, J.I.; Rotimi, J.; Opoggen, L.; Egbon, I.N.; Uyi, O.O. Phytochemical constituents and larvicidal efficacy of methanolic extracts of Cymbopogon citratus, Ocimum gratissimum and Vernonia amygdalina against Culex quinquefasciatus larvae. JASEM 2019, 23, 701-709. [CrossRef]

20. Chiluwal, K.; Kim, J.; Do Bae, S.; Park, C.G. Essential oils from selected wooden species and their major components as repellents and oviposition deterrents of Callosobruchus chinensis (L.). J. Asia Pac. Entomol. 2017, 20, 1447-1453. [CrossRef]

21. Wagner, R.L.; Card, J.A. Ailanthus altissima aqueous extract deters Spodoptera frugiperda oviposition. Great Lakes Entomol. 2020, 53, 68-72.

22. Gaur, S.K.; Kumar, K. Toxicity and insect growth regulatory effects of root extract from the medicinal plant, Withania somnifera (Linnaeus) against red flour beetle, Tribolium castaneum (Coleoptera: Tenebrionidae). Arch. Phytopathol. Pflanzenschutz 2020, 53, 856-875. [CrossRef]

23. Dudareva, N.; Negre, F.; Nagegowda, D.A.; Orlova, I. Plant volatiles: Recent advances and future perspectives. Crit. Rev. Plant Sci. 2007, 25, 417-440. [CrossRef]

24. Riffel, A.; Da Costa, J.G. Os Voláteis de Plantas e o Seu Potencial para a Agricultura; Embrapa Tabuleiros Costeiros: Aracaju, Brazil, 2015; 48p.

25. Cook, S.M.; Khan, Z.R.; Pickett, J.A. The use of push-pull strategies in integrated pest management. Annu. Rev. Entomol. 2007, 52, 375-400. [CrossRef] [PubMed] 
26. Silva, S.E.; Auad, A.M.; Moraes, J.C.; Alvarenga, R.; Fonseca, M.G.; Marques, F.A.; Santos, N.C.S.; Nagata, N. Olfactory response of Mahanarva spectabilis (Hemiptera: Cercopidae) to volatile organic compounds from forage grasses. Sci. Rep. 2019, 9, 10284. [CrossRef] [PubMed]

27. Ayres, M.; Ayres, J.R.M.; Ayres, D.L.; Santos, A.S.B. 5.3: Aplicações Estatísticas nas Áreas das Ciências Biológicas e Médicas; Publicações Avulsas do Mamirauá: Belém, Brazil, 2011;361p.

28. São João, R.E.; Raga, A. Mecanismo de Defesa Das Plantas Contra o Ataque de Insetos Sugadores; Instituto Biológico-APTA: São Paulo, Brazil, 2016; 13p.

29. Singh, D.; Singh, A.K. Repellent and insecticidal properties of essential oils against housefly, Musca domestica L. Int. J. Trop. Insect Sci. 1991, 12, 487-491. [CrossRef]

30. Wei, L.; Hua, R.; Li, M.; Huang, Y.; Li, S.; He, Y.; Shen, Z. Chemical composition and biological activity of star anise Illicium verum extracts against maize weevil, Sitophilus zeamais adults. J. Insect Sci. 2014, 14, 80. [CrossRef]

31. Matos, L.F.; Barbosa, D.R.S.; de Andrade Dutra, K.; Dutra, K.D.A.; Navarro, D.M.D.A.F.; Alves, J.L.R.; Silva, G.N. Chemical composition and insecticidal effect of essential oils from Illicium verum and Eugenia caryophyllus on Callosobruchus maculatus in cowpea. Ind. Crop. Prod. 2020, 145, 112088. [CrossRef]

32. Singh, G.; Maurya, S.; Delampasona, M.P.; Catalan, C. Chemical constituents, antimicrobial investigations and antioxidative potential of volatile oil and acetone extract of star anise fruits. J. Sci. Food Agric. 2005, 86, 111-121. [CrossRef]

33. Braibante, M.E.F.; Zappe, J.A. A química dos agrotóxicos. Quím. Nova Esc. 2012, 34, 10-15.

34. Mendes, A.M.S.; Souza, M.M.S.; Fonseca, A.M.; Colares, R.P.; Carneiro, J.B.; Santos, F.G.N. Inseticidas naturais: Uma alternativa sustentável para o controle de pragas na agricultura familiar. In Proceedings of the $56^{\circ}$ Congresso Brasileiro de Química (Online), Belém, Brazil, 7-11 November 2016; ABQ: Rio de Janeiro, Brazil, 2016.

35. Silva, L.M.; Caldas, A.P.; Rodrigues, A.L.M.; Oliveira, J.S.; de Sousa Simonetti, E.R. O uso do extrato de fumo (Nicotina tabacum) como alternativa para o controle de pragas em hortaliças. In Proceedings of the II Congresso Internacional Das Ciências Agrárias, Natal, Brazil, 4-8 December 2017; PDV Agro: Natal, Brazil, 2017.

36. Sagheer, M.; Ali, K.; Rashid, A.; Sagheer, U.; Alvi, A. Repellent and toxicological impact of acetone extracts of Nicotiana tabacum, Pegnum hermala, Saussurea costus and Salsola baryosma against red flour beetle, Tribolium castaneum (Herbst). Pak. J. Zool. 2013, 45, 1735-1739.

37. Dougoud, J.; Toepfer, S.; Bateman, M.; Jenner, W.H. Efficacy of homemade botanical insecticides based on traditional knowledge. A review. Agron. Sustentar Dev. 2019, 39, 37. [CrossRef]

38. Tayoub, G.; Sulaiman, H.; Alorf, M. Determination of nicotine levels in the leaves of some Nicotiana tabacum varieties cultivated in Syria. Herba Pol. 2016, 61, 23-30. [CrossRef]

39. González-Guiñez, R.; Silva-Aguayo, G.; Urbina-Parra, A.; Gerding-González, M. Aceite esencial de Eucalyptus globulus Labill y Eucalyptus nitens H. Deane \& Maiden (myrtaceae) para el control de Sitophilus zeamais Motschulsky. Chil. J. Agric. Anim. Sci. 2016, 32, 204-216.

40. Descamps, L.R.; Bizet Turovsky, J.A.J.; Brustle, C.M.; Sánchez Chopa, F. Actividad repelente del aceite esencial de Eucalyptus globulus Labill. (Myrtaceae) y Mentha x piperita L. (Lamiaceae) en Acyrthosiphon pisum Harris (Hemiptera: Aphididae). Dominguezia 2019, 35, 93-96.

41. Leyva, M.; Marquetti, M.d.C.; Montada, D.; Payroll, J.; Scull, R.; Morejón, G.; Pino, O. Aceites esenciales de Eucalyptus globulus (Labill) y Bursera graveolens (kunth) Triana \& Planch para el control de mosquitos de importancia médica. Biologist 2020, 18, 239-250.

42. Mobki, M.; Safavi, S.A.; Safaralizadeh, M.H.; Panahi, O. Toxicity and repellency of garlic (Allium sativum L.) extract grown in Iran against Tribolium castaneum (Herbst) larvae and adults. Arch. Phytopathol. Pflanzenschutz 2014, 47, 59-68. [CrossRef]

43. Perera, A.G.W.U.; Karunaratne, M.M.S.C. Eco-Friendly alternatives for storage pest management: Leaves of Ruta graveolens (aruda) as a repellent against the rice Weevil, Sitophilus oryzae L. Int. J. Interdiscip. Multidiscip. Stud. 2015, 2, 49-56. [CrossRef]

44. Prajapati, V.; Tripathi, A.K.; Aggarwal, K.K.; Khanuja, S.P.S. Insecticidal, repellent and oviposition-deterrent activity of selected essential oils against Anopheles stephensi, Aedes aegypti and Culex quinquefasciatus. Bioresour. Technol. 2005, 96, 1749-1757. [CrossRef]

45. Kimutai, A.; Ngeiywa, M.; Mulaa, M.; Njagi, P.G.N.; Ingonga, J.; Nyamwamu, L.B.; Ombati, C.; Ngumbi, P. Repellent effects of the essential oils of Cymbopogon citratus and Tagetes minuta on the sandfly, Phlebotomus duboscqi. BMC Res. Notes 2017, 10, 98. [CrossRef] [PubMed]

46. Picard, I.; Hollingsworth, R.G.; Salmieri, S.; Lacroix, M. Repellency of essential oils to Frankliniella occidentalis (Thysanoptera: Thripidae) as affected by type of oil and polymer release. J. Econ. Entomol. 2012, 105, 1238-1247. [CrossRef]

47. Kumar, S.; Singh, A. Biopesticides: Present Status and the Future Prospects. J. Fertil. Pestic. 2015, 6, e129. [CrossRef] 